\section{Extent of teachers' integration of environmental awareness and sustainable development practices in selected elementary schools in Taytay District: An action plan}

\author{
Nasol, Reyna Jolla $\measuredangle$ \\ Emilio Aguinaldo College, Philippines (reynajolla.nasol@deped.gov.ph)
}

Received: 30 March 2021

Available Online: 13 July 2021
Revised: 17 May 2021 DOI: $10.5861 /$ ijrse.2021.660

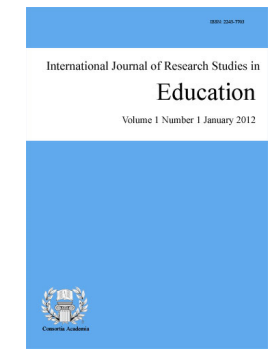

ISSN: 2243-7703 Online ISSN: 2243-7711

OPEN ACCESS

\title{
Abstract
}

This study covered the relationship between the extent of the teachers' integration of environmental awareness in terms of waste management, pollution, forest conservation, and climate change with sustainable development practices. As assessed by the heads and teacherrespondents classified as to proper waste disposal, recycling, composting, tree planting, and energy conservation. There will be 63 heads and 177 teachers from eight public elementary schools in the Province of Rizal, who will be tasked to answer the specific research questions. It can be concluded that most of the respondents are rank and file teachers since only some are heads. As with gender, this research is dominated by female and whose age ranges from late and young adulthood. This means that both groups (heads and teachers) are matured enough and have knowledge regarding environmental awareness and sustainable development. There is a moderate extent of integration on environmental awareness as assessed in terms of waste management, pollution; forest conservation; and climate change which means that both heads and teachers should update environmental concepts. And to examine and contextualize environmental issues better and provide sufficient learning outcomes. Maximize the opportunity to sustain and improve the cooperation of local and national agencies to utilize more efficient and unified information on environmental education. Though there is a significant difference between the assessment in terms of the extent of integration of environmental awareness; and sustainable development practices, heads and teachers must work hand in hand in delivering education for sustainability since environmental awareness provides important opportunities for students to become engaged in real world issues that transcend classroom walls. They can see the relevance of their classroom studies to the complex environmental issues confronting our planet. They can acquire the skills they will need to be creative problem solvers and powerful advocates.

Keywords: teachers' integration, environmental awareness, sustainable development practices, transcend, climate change 


\section{Extent of teachers' integration of environmental awareness and sustainable development practices in selected elementary schools in Taytay District: An action plan}

\section{Introduction}

Sustainability is a serious issue around the globe. It is a global responsibility based merely on international, regional, and local laws under critical planning and strict implementation. The social, environmental, and economic foundations can be accomplished by good organization and active community engagement by promoting sustainable development. Sustainable development establishes linkage in retort to ecological issues in consort with industrial development and technical invention. Some countries, particularly poor countries worldwide, find sustainability to be costly to pursue, and most of them are not happy with other nations ' commitment to viable growth. Nevertheless, it is the government's responsibility not to rely on the belief that environmental issues should be set aside until they become wealthier (Sachs, 2012).

The Philippines, being a third-world country, definitely its major stimulating task is to revitalize its legacy as "The Asian Tiger Economy," and to create a stable and well-balanced society for industrial-environmental conservation. Although there are few government sectors for the environment, crop growing, fitness, and education collaborate in achieving an objective of maintainable growth of the rural area. However, Filipinos rely on survival and improvement of the economic situation. This rising landscape rests in the notion of practicality rather than idealism. It is perhaps the least sustainable level. It is more likely that people do something for a particular reward. This habit was caused by unsuitable teaching, instruction, and preparation. Indeed, training younger generations to improve their concepts for a better future is a challenging task. Certainly, it is a test of ability for teachers to empower the youth not only with information and successes but also to be conscious of how to overcome environmental concerns and problems globally. In the case of teachers, therefore, the knowingness, care, and affection for the environment should have been inserted into the students' minds, and these involve cognitive, affective, psychomotor-based education through incorporating all learning concepts (Ravago et al., 2009).

The law mandated the recognized educational system to conform in the commissariat of the Philippine Constitution, for instance, Presidential Decree 1152, Republic Act No. 9512, DepEd Order No. 72, s. 2003, DepEd Order No. 52, s. 2011, and DepEd Memorandum No. 133, s. 2014. Teachers, instructors, professors, and school administrators are summoned to inculcate partisan, societal, moral, and ethics of compassionate students to achieve and maintain the aids of involvement in sustainable development (Baring et al., 2020).

\subsection{Significance of the study}

The research will benefit the succeeding stakeholders:

Department of Education. This government agency will be enlightened on the present situation on how the teachers integrate their awareness of the environment and practices in sustainable development in the nominated schools in the province of Rizal. Policies, procedures, and the K to 12 curriculums may be revisited to effectively integrate environmental protection.

Schools Division Office. Environmental protection programs may be enhanced/ improved through increased awareness and sustainable development. They could also call for a more aggressive implementation of the instituted policies.

School Administrators. They will be enlightened of the present situation in their midst. Hence, they may instigate interventions that deliver quality integration of environmental awareness and sustainability. They may also use the recommendations for internal policy formulation along the area of environmental protection. 
Teachers' integration of environmental awareness and sustainable development practices in elementary schools

Teachers. They will realize that their efforts in protecting their pupils in the classroom are sustainable and responsive.

Parents. They will ensure that the stakeholders in the schools are doing their job to the extent of their abilities under the commands of the Department of Education through the supervision of the Schools Division Office as regards environmental programs.

Researchers. They may pursue studies aligned with environmental protection in schools and communities.

\section{Methodology}

Descriptive research design is used in this study. It is a scientific method wherein the behavior of a subject is observed and described without the use of influence. It aimed to consolidate the environmental awareness and sustainable development of select teachers in public elementary schools in the Taytay District as evaluated by themselves. The simple random technique was employed in this study. A simple random sample is taken to represent the whole population. Lotteries and random draws are examples of techniques to create a random sample. The study participants are the administrators and teachers of the chosen elementary schools in Taytay District- Sta. Ana Elementary School (SAES), San Isidro Elementary School (SIES), Hapay na Mangga Elementary School (HMES), Corazon C. Aquino Elementary School CCAES), Taytay Elementary School (TES), Felix M. Sanvictores Elementary School (FMSES), Sitio Tapayan Elementary School (STES), Sitio Simona Elementary School (SSES). The administrators, as well as the teachers, were randomly selected regardless of age and sex.

This study employed a researcher-modified instrument based on Labog (2017) on the Teachers' Integration of Environmental Awareness and Sustainable Development Practices in eight chosen schools Taytay District in Rizal. The instrument contains three parts. The first part determined the administrators and teachers' rank, sex, and age. The second part determined the Extent of Teachers' Integration of Environmental Awareness assessment in terms of conservation of forests, managing waste, climate change, and pollution. Finally, part three contains the Teachers' Level of Sustainable Development Practices assessment as to proper waste disposal, tree planting, composting, recycling, planting of trees, and conservation of energy.

\section{Results and discussion}

The researcher utilized a descriptive-survey method as the method used in this study to gather the data regarding the extent of consciousness regarding the environment and practices for sustainable development in chosen elementary schools around the District of Taytay. Quantitative and qualitative methods are used in the descriptive research design to investigate one or even more variables. The aim is to accurately describe the population, phenomenon, and situation thoroughly. To identify the cause and effect, experimental research is required. It also helped generate a comprehensive account that will present the reality of the participants in a dynamic manner. Furthermore, the descriptive method is designed to depict the participants in an accurate way. Most ( $f=177,100$ percent) of the respondents are teachers; while, the remaining $(f=63,100$ percent) are administrators. This information indicates that most respondents are of rank-and-file position while some are of supervisory level.

\section{Table 1}

Position distribution of respondents

\begin{tabular}{rcccc}
\hline \multirow{2}{*}{ Category } & \multicolumn{2}{c}{ Administrators } & \multicolumn{2}{c}{ Teachers } \\
\cline { 2 - 5 } & Frequency & Percent & Frequency & Percent \\
\hline Total & 63 & $100.0 \%$ & 177 & $100.0 \%$ \\
\hline
\end{tabular}

For the administrators, most ( $\mathrm{f}=55,87.3$ percent $)$ of the respondents are female, while few ( $\mathrm{f}=8,12.7$ percent) are male. Also, with teachers, several $(\mathrm{f}=164,92.7$ percent $)$ of the respondents are female; while some $(\mathrm{f}=13$, 7.3 percent) are male. This indicates that the study is female dominant since only a few are male. 
Nasol, R. J.

Table 2

Gender distribution of respondents

\begin{tabular}{lcccc}
\hline \multirow{2}{*}{ Category } & \multicolumn{2}{c}{ Administrators } & \multicolumn{2}{c}{ Teachers } \\
\cline { 2 - 5 } & Frequency & Percent & Frequency & Percent \\
\hline Male & 8 & $12.7 \%$ & 13 & $7.3 \%$ \\
female & 55 & $87.3 \%$ & 164 & $92.7 \%$ \\
\hline Total & 63 & $100.0 \%$ & 177 & $100.0 \%$ \\
\hline
\end{tabular}

Several ( $\mathrm{f}=28,44.4$ percent) of the administrators are between or equal to the age range of 41-50 years old, some ( $\mathrm{f}=17,27.0$ percent) are between or equal to the age range $31-40$ years old; and a few ( $\mathrm{f}=1,1.6$ percent) are equal to or above 61 years old. With the teachers, most $(f=68,38.4$ percent) are between or equal to the age range 31-40 years old; various ( $\mathrm{f}=48,27.1$ percent) are equal to or above 30 years old; and only $(\mathrm{f}=1, .6 \%)$ a few are equal to or above 61 years old. Overall, there is a predominance of late adulthood in the administrators and a predominance of middle adulthood in the teachers. Both sets of respondents have very few retiring teachers or administrators.

Table 3

Age distribution of respondents

\begin{tabular}{|c|c|c|c|c|}
\hline \multirow{2}{*}{ Category } & \multicolumn{2}{|c|}{ Administrators } & \multicolumn{2}{|c|}{ Teachers } \\
\hline & Frequency & Percent & Frequency & Percent \\
\hline$<=30$ years old & 4 & $6.3 \%$ & 48 & $27.1 \%$ \\
\hline $31-40$ years old & 17 & $27.0 \%$ & 68 & $38.4 \%$ \\
\hline $41-50$ years old & 28 & $44.4 \%$ & 46 & $26.0 \%$ \\
\hline $51-60$ years old & 13 & $20.6 \%$ & 14 & $7.9 \%$ \\
\hline$>=61$ years old & 1 & $1.6 \%$ & 1 & $.6 \%$ \\
\hline & 63 & $100.0 \%$ & 177 & $100.0 \%$ \\
\hline
\end{tabular}

Regarding the integration of the teacher's environmental awareness with pollution, the composite mean value of 3.30 with SD of .44418 for heads and 3.28 composite mean value with SD of .45647 for teachers indicates that both respondents have a moderate extent of integration. However, this means that waste management has not been fully employed, and there is a need to further enhance the system.

\section{Table 4}

Teachers' integration of environmental awareness as assessed by the two groups in terms of waste management

\begin{tabular}{|c|c|c|c|c|c|c|}
\hline \multirow{2}{*}{ Indicator } & \multicolumn{3}{|c|}{ Administrators } & \multicolumn{3}{|c|}{ Teachers } \\
\hline & Mean & SD & $\mathrm{VI}$ & Mean & SD & VI \\
\hline $\begin{array}{l}\text { 1. encourages pupils to develop } \\
\text { own processes of waste } \\
\text { management both in school and at } \\
\text { home }\end{array}$ & 3.57 & .53019 & VEI & 3.63 & .51890 & VEI \\
\hline 2. sets fixed standards & 3.41 & .49627 & ME I & 3.38 & .60244 & ME I \\
\hline $\begin{array}{l}\text { 3. manages time and provides } \\
\text { needed data }\end{array}$ & 3.31 & .53356 & ME I & 3.29 & .55547 & ME I \\
\hline $\begin{array}{l}\text { 4. proper designation and } \\
\text { segregation of pupils }\end{array}$ & 3.46 & .59094 & ME I & 3.47 & .56476 & ME I \\
\hline 5. conducts recurring assessment & 3.11 & .65034 & ME I & 3.20 & .61551 & ME I \\
\hline $\begin{array}{l}\text { 6. encourage pupils to take part on } \\
\text { government programs }\end{array}$ & 3.49 & .56434 & VEI & 3.39 & .61284 & ME I \\
\hline $\begin{array}{l}\text { 7. introduces innovations and } \\
\text { developments }\end{array}$ & 3.17 & .63601 & ME I & 3.10 & .72366 & ME I \\
\hline $\begin{array}{l}\text { 8.invites key speakers from } \\
\text { notable departments for fora and } \\
\text { seminars about waste mgmt. }\end{array}$ & 2.84 & .91944 & ME I & 2.78 & .87388 & ME I \\
\hline Composite Mean & 3.30 & .44418 & MEI & 3.28 & .45647 & MEI \\
\hline
\end{tabular}

Legend: $3.50-4.00=$ High Extent of Integration (VEI); $2.50-3.49$ Moderate Extent of Integration (MEI); $1.50-2.49=$ Less Extent of Integration (LEI); $1.00-1.49=$ No Integration (NI)

On the extent of the administrators and integration of teachers of awareness in the environment in terms of pollution, the composite means and SDs of 3.38, .44925 and 3.32, .45216 for heads and teachers respectively imply that both groups have the moderate extent of integration when it comes to integrating pollution.

48 Consortia Academia Publishing (A partner of Network of Professional Researchers and Educators) 
Teachers' integration of environmental awareness and sustainable development practices in elementary schools

Table 5

Teachers' integration of environmental awareness as assessed by the two groups in terms of pollution

\begin{tabular}{|c|c|c|c|c|c|c|}
\hline \multirow{2}{*}{ Indicator } & \multicolumn{3}{|c|}{ Administrators } & \multicolumn{3}{|c|}{ Teachers } \\
\hline & Mean & SD & VI & Mean & SD & VI \\
\hline 1.provides pupils with necessary & 3.51 & .53500 & VEI & 3.41 & .52609 & \\
\hline $\begin{array}{l}\text { information on effects to health of } \\
\text { humans }\end{array}$ & & & & & & MEI \\
\hline $\begin{array}{l}\text { 2.plays as role models to inform } \\
\text { them simply the effects of } \\
\text { pollution }\end{array}$ & 3.57 & .49885 & VEI & 3.48 & .52322 & MEI \\
\hline $\begin{array}{l}\text { 3.explains where waste pollutants } \\
\text { are generated in school }\end{array}$ & 3.48 & .56389 & MEI & 3.43 & .57092 & MEI \\
\hline $\begin{array}{l}\text { 4.provides simple ways to } \\
\text { understand theories and practices } \\
\text { to reduce pollution }\end{array}$ & 3.29 & .63318 & MEI & 3.25 & .57188 & MEI \\
\hline $\begin{array}{l}\text { 5.encourages pupils to use } \\
\text { alternative products to help the } \\
\text { environment }\end{array}$ & 3.56 & .58964 & VEI & 3.45 & .60228 & MEI \\
\hline $\begin{array}{l}\text { 6.encourages pupils to actively } \\
\text { take part in programs that help the } \\
\text { environment }\end{array}$ & 3.35 & .59997 & MEI & 3.25 & .69723 & MEI \\
\hline $\begin{array}{l}\text { 7.provides guidelines to help } \\
\text { reduce production of pollutants }\end{array}$ & 3.21 & .72198 & MEI & 3.16 & .64654 & MEI \\
\hline $\begin{array}{l}\text { 8.encourages pupils to conduct } \\
\text { regular checking around the } \\
\text { community regarding pollution }\end{array}$ & 3.10 & .79746 & MEI & 3.15 & .74193 & MEI \\
\hline Composite Mean & 3.38 & .44925 & MEI & 3.32 & .45216 & MEI \\
\hline
\end{tabular}

On the extent of the teachers' integration of environmental awareness as assessed by the two groups in terms of forest conservation, both administrators and teachers have a moderate extent of integration on forest conservation with composite mean and SD of $3.24, .554543 .21, .53326$ correspondingly.

Table 6

Teachers' integration of environmental awareness as assessed by the two groups in terms of forest conservation

\begin{tabular}{|c|c|c|c|c|c|c|}
\hline \multirow{2}{*}{ Indicator } & \multicolumn{3}{|c|}{ Administrators } & \multicolumn{3}{|c|}{ Teachers } \\
\hline & Mean & SD & VI & Mean & SD & VI \\
\hline $\begin{array}{l}\text { 1.provides information on the } \\
\text { significance of trees and forests to } \\
\text { life }\end{array}$ & 3.33 & .67202 & MEI & 3.41 & .57757 & MEI \\
\hline $\begin{array}{l}\text { 2.involves the school body in } \\
\text { government programs regarding } \\
\text { forest reconstruction }\end{array}$ & 3.17 & .75219 & MEI & 3.19 & .66078 & MEI \\
\hline $\begin{array}{l}\text { 3.imparts to the pupils the } \\
\text { obligation in reporting illegal } \\
\text { logging practices }\end{array}$ & 3.21 & .67582 & MEI & 3.28 & .67181 & MEI \\
\hline $\begin{array}{l}\text { 4.encourages pupils to take part in } \\
\text { forest reconstruction and } \\
\text { conservation programs }\end{array}$ & 3.25 & .64678 & MEI & 3.27 & .66793 & MEI \\
\hline $\begin{array}{l}\text { 5.encourages pupils to distribute } \\
\text { information on wildlife } \\
\text { conservation }\end{array}$ & 3.22 & .68261 & MEI & 3.16 & .67525 & MEI \\
\hline $\begin{array}{l}\text { 6.familiarizes pupils with } \\
\text { environmental programs of local } \\
\text { and national offices }\end{array}$ & 3.24 & .73428 & MEI & 3.13 & .65718 & MEI \\
\hline $\begin{array}{l}\text { 7.encourages pupils to take part in } \\
\text { promotions about forest } \\
\text { preservation }\end{array}$ & 3.25 & .69487 & MEI & 3.18 & .71595 & MEI \\
\hline $\begin{array}{l}\text { 8.encourages pupils to join in } \\
\text { DepEd approved organizations } \\
\text { that promote forest preservation }\end{array}$ & 3.21 & .69928 & MEI & 3.09 & .71729 & MEI \\
\hline Composite Mean & 3.24 & .55454 & MEI & 3.21 & .53326 & MEI \\
\hline
\end{tabular}

Legend: $3.50-4.00=$ High Extent of Integration (VEI); $2.50-3.49$ Moderate Extent of Integration (MEI); $1.50-2.49=$ Less Extent of Integration (LEI); $1.00-1.49=$ No Integration (NI)

On the extent of the teachers' integration of environmental awareness as assessed by the two groups in terms of climate change, heads have a composite mean of 3.18 and SD of .48808 , while teachers have a 3.17 composite 
Nasol, R. J.

mean and SD of .52470 . Thus, both groups have a moderate extent of integration on climate change.

\section{Table 7}

Teachers' integration of environmental awareness as assessed by the two groups in terms of climate change

\begin{tabular}{|c|c|c|c|c|c|c|}
\hline \multirow{2}{*}{ Indicator } & \multicolumn{3}{|c|}{ Administrators } & \multicolumn{3}{|c|}{ Teachers } \\
\hline & Mean & SD & VI & Mean & SD & VI \\
\hline $\begin{array}{l}\text { 1.develops positive attitude of } \\
\text { students on risk reduction and } \\
\text { disaster preparedness }\end{array}$ & 3.46 & .59094 & MEI & 3.49 & .54480 & MEI \\
\hline $\begin{array}{l}\text { 2.updates pupils on current issues } \\
\text { regarding climate change on the } \\
\text { environment at life }\end{array}$ & 3.40 & .55474 & MEI & 3.31 & .62117 & MEI \\
\hline $\begin{array}{l}\text { 3.manages time by sharing } \\
\text { practices related to climate } \\
\text { change }\end{array}$ & 3.25 & .59482 & MEI & 3.27 & .65070 & MEI \\
\hline $\begin{array}{l}\text { 4.enhances awareness of pupils by } \\
\text { involving them in programs } \\
\text { related to climate change }\end{array}$ & 3.35 & 62627 & MEI & 3.23 & .65262 & MEI \\
\hline $\begin{array}{l}\text { 5. encourages pupils to take part } \\
\text { in informing and dissemination } \\
\text { activities regarding climate } \\
\text { change both at home and in } \\
\text { school }\end{array}$ & 3.35 & .59997 & MEI & 3.24 & .66808 & MEI \\
\hline $\begin{array}{l}\text { 6.initiates activities regarding } \\
\text { climate change education with the } \\
\text { means of programs observed } \\
\text { scientifically }\end{array}$ & 3.11 & .72091 & MEI & 3.12 & .62390 & MEI \\
\hline $\begin{array}{l}\text { 7.invites key speakers to develop } \\
\text { pupils intellectually regarding } \\
\text { climate change and preparedness } \\
\text { for disaster-risk events }\end{array}$ & 2.84 & .88366 & MEI & 2.88 & .83007 & Mei \\
\hline $\begin{array}{l}\text { 8.conducts seminars with key } \\
\text { speakers from notable } \\
\text { departments, like DENR, DoA, } \\
\text { and other government and } \\
\text { non-government departments for } \\
\text { seminars regarding climate } \\
\text { change }\end{array}$ & 2.65 & .78614 & Mei & 2.84 & .82658 & MEI \\
\hline
\end{tabular}

Legend: $3.50-4.00=$ High Extent of Integration (VEI); $2.50-3.49$ Moderate Extent of Integration (MEI); $1.50-2.49=$ Less Extent of Integration (LEI); $1.00-1.49=$ No Integration (NI)

Regarding the level of practice in sustainable development as assessed by the grouped respondents in terms of proper waste disposal, administrators have a composite mean of 3.30 with an SD of .49106. In contrast, teachers have a composite mean of 3.23 with an SD of .51414 . This means that both groups have practiced waste disposal for sustainable development.

\section{Table 8}

Sustainable development practices as assessed by the grouped respondents in terms of proper waste disposal

\begin{tabular}{|c|c|c|c|c|c|c|}
\hline \multirow{2}{*}{ Indicator } & \multicolumn{3}{|c|}{ Administrators } & \multicolumn{3}{|c|}{ Teachers } \\
\hline & Mean & SD & VI & Mean & SD & VI \\
\hline $\begin{array}{l}\text { 1.designates area around the } \\
\text { school for proper disposal with } \\
\text { the use of garbage cans }\end{array}$ & 3.59 & .52777 & HP & 3.58 & .58978 & $\mathrm{HP}$ \\
\hline $\begin{array}{l}\text { 2.sets regulations around the } \\
\text { school on standard waste } \\
\text { management }\end{array}$ & 3.59 & .58571 & HP & 3.45 & .61164 & $\mathrm{P}$ \\
\hline $\begin{array}{l}\text { 3.adapts activities from other } \\
\text { schools and implements the } \\
\text { recommended solid waste } \\
\text { management practices }\end{array}$ & 3.51 & .56434 & HP & 3.40 & .59601 & $\mathrm{P}$ \\
\hline $\begin{array}{l}\text { 4. occasionally monitors the } \\
\text { proper disposal of wastes to limit } \\
\text { the foul odor production }\end{array}$ & 3.48 & .53452 & $\mathrm{P}$ & 3.31 & .59309 & $\mathrm{P}$ \\
\hline $\begin{array}{l}\text { 5. properly segregates waste } \\
\text { based on appropriate segregation } \\
\text { categories }\end{array}$ & 3.37 & .60379 & $\mathrm{P}$ & 3.30 & .64460 & $\mathrm{P}$ \\
\hline
\end{tabular}


Teachers' integration of environmental awareness and sustainable development practices in elementary schools

\begin{tabular}{|c|c|c|c|c|c|c|}
\hline $\begin{array}{l}\text { 6. organizing seminars for pupils } \\
\text { on how to effectively segregate } \\
\text { waste }\end{array}$ & 2.92 & .88539 & P & 2.96 & .82821 & $\mathrm{P}$ \\
\hline $\begin{array}{l}\text { 7.supports activities like } \\
\text { maintenance for waste disposal } \\
\text { around school by providing } \\
\text { financial help }\end{array}$ & 2.98 & .77235 & $\mathrm{P}$ & 2.86 & .81445 & $\mathrm{P}$ \\
\hline $\begin{array}{l}\text { 8. synchronizes collection of } \\
\text { waste with respective government } \\
\text { units }\end{array}$ & 2.95 & .83141 & $\mathrm{P}$ & 2.99 & .79413 & $\mathrm{P}$ \\
\hline Composite Mean & 3.30 & .49106 & $\mathrm{P}$ & 3.23 & .51414 & $P$ \\
\hline
\end{tabular}

On the level of sustainable development practices assessed by the grouped respondents in terms of recycling, both heads and teachers are gauged as "practiced" with composite means and SDs of 3.34, .49555, and $3.33, .51546$ respectively.

\section{Table 9}

Level of sustainable development practices as assessed by the grouped respondents in terms of recycling

\begin{tabular}{|c|c|c|c|c|c|c|}
\hline \multirow{2}{*}{ Indicator } & \multicolumn{3}{|c|}{ Administrators } & \multicolumn{3}{|c|}{ Teachers } \\
\hline & Mean & SD & VI & Mean & SD & VI \\
\hline $\begin{array}{l}\text { 1.imparts the importance of the } \\
\text { 3Rs (reduce, reuse, recycle) to the } \\
\text { pupils }\end{array}$ & 3.57 & .55979 & HP & 3.58 & .57019 & HP \\
\hline $\begin{array}{l}\text { 2.engages in simple practices in } \\
\text { recycling }\end{array}$ & 3.54 & .53356 & HP & 3.52 & .57495 & HP \\
\hline 3. separates recyclable materials & 3.49 & .59224 & $\mathrm{P}$ & 3.41 & .64355 & $\mathrm{P}$ \\
\hline $\begin{array}{l}\text { 4.imparts importance of } \\
\text { conservation and proper use of } \\
\text { school supplies }\end{array}$ & 3.46 & .53356 & $\mathrm{P}$ & 3.41 & .60721 & $\mathrm{P}$ \\
\hline $\begin{array}{l}\text { 5.demonstrates methods of } \\
\text { recyclable materials proper } \\
\text { storage }\end{array}$ & 3.38 & .58000 & $\mathrm{P}$ & 3.33 & .65424 & $\mathrm{P}$ \\
\hline $\begin{array}{l}\text { 6.produces income from } \\
\text { junkshops from collected wastes }\end{array}$ & 3.13 & .77235 & $\mathrm{P}$ & 3.21 & .71217 & $\mathrm{P}$ \\
\hline $\begin{array}{l}\text { 7. designates a Materials } \\
\text { Recovery Facility (MRF) } \\
\text { specifically inside the school }\end{array}$ & 3.30 & .61263 & $\mathrm{P}$ & 3.27 & .71716 & $\mathrm{P}$ \\
\hline $\begin{array}{l}\text { 8.invites key persons from DENR } \\
\text { or various departments that } \\
\text { provide recycling proper training }\end{array}$ & 2.86 & .89546 & $\mathrm{P}$ & 2.91 & .91252 & $\mathrm{P}$ \\
\hline Composite Mean & 3.34 & .49555 & $\mathrm{P}$ & 3.33 & .51546 & $\mathrm{P}$ \\
\hline
\end{tabular}

Legend: $3.50-4.00=$ Practiced Highly (HP); $2.50-3.49=$ Practiced (P); $1.50-2.49=$ Practiced Moderately (MP); $1.00-1.49=$ Less Practiced (LP)

On the level of sustainable development practices assessed by the grouped respondents in composting, administrators have a composite mean of 2.95 and SD of .73185. In contrast, teachers have a composite mean of 3.09 and an SD of .65836. Thus, both groups have practiced composting as part of sustainable development.

\section{Table 10}

Level of sustainable development practices as assessed by the grouped respondents in terms of composting

\begin{tabular}{|c|c|c|c|c|c|c|}
\hline \multirow{2}{*}{ Indicator } & \multicolumn{3}{|c|}{ Administrators } & \multicolumn{3}{|c|}{ Teachers } \\
\hline & Mean & SD & VI & Mean & SD & $\mathrm{VI}$ \\
\hline $\begin{array}{l}\text { 1. segregates recyclable wastes to } \\
\text { be treated }\end{array}$ & 3.14 & .77993 & $\mathrm{P}$ & 3.38 & .73807 & $\mathrm{P}$ \\
\hline $\begin{array}{l}\text { 2.encourages use of organic } \\
\text { farming to promote effects in the } \\
\text { environment and human life }\end{array}$ & 3.13 & .83264 & $\mathrm{P}$ & 3.26 & .76887 & $\mathrm{P}$ \\
\hline $\begin{array}{l}\text { 3.uses fertilizers for organic } \\
\text { gardening }\end{array}$ & 3.00 & .84242 & $\mathrm{P}$ & 3.11 & .78963 & $\mathrm{P}$ \\
\hline $\begin{array}{l}\text { 4. promotes composting to } \\
\text { students both at home and in } \\
\text { school }\end{array}$ & 3.22 & .75015 & $\mathrm{P}$ & 3.21 & .74560 & $\mathrm{P}$ \\
\hline
\end{tabular}




\begin{tabular}{|c|c|c|c|c|c|c|}
\hline $\begin{array}{l}\text { 5. composts to convert } \\
\text { biodegradable wastes to organic } \\
\text { fertilizers }\end{array}$ & 3.05 & .79166 & $\mathrm{P}$ & 3.07 & .78039 & $\mathrm{P}$ \\
\hline $\begin{array}{l}\text { 6. gives financial support in } \\
\text { school to show composting } \\
\text { resourcefulness }\end{array}$ & 2.86 & .89546 & $\mathrm{P}$ & 2.95 & .84490 & $\mathrm{P}$ \\
\hline $\begin{array}{l}\text { 7.provides seminars to increase in } \\
\text { composting knowledge }\end{array}$ & 2.65 & .95307 & $\mathrm{P}$ & 2.90 & .86658 & $\mathrm{P}$ \\
\hline $\begin{array}{l}\text { 8. invites key speakers from } \\
\text { DENR, DAR, or other } \\
\text { departments that provide proper } \\
\text { training in composting }\end{array}$ & 2.54 & 1.01323 & $\mathrm{P}$ & 2.79 & .88954 & $\mathrm{P}$ \\
\hline Composite Mean & 2.95 & .73185 & $\mathrm{P}$ & 3.09 & .65836 & $\mathrm{P}$ \\
\hline
\end{tabular}

Legend: $3.50-4.00=$ Practiced Highly $(\mathrm{HP}) ; 2.50-3.49=$ Practiced $(\mathrm{P}) ; 1.50-2.49=$ Practiced Moderately $(\mathrm{MP}) ; 1.00-1.49=\mathrm{Less}$ Practiced (LP)

On the level of sustainable development practices assessed by the grouped respondents in terms of tree planting, with a composite mean of 2.95 and SD of .69942 for administrators and 3.02 composite mean and SD .65992 for teachers, both groups have practiced tree planting as part of their sustainable development activity.

\section{Table 11}

Level of sustainable development practices as assessed by the grouped respondents in terms of tree planting

\begin{tabular}{|c|c|c|c|c|c|c|}
\hline \multirow{2}{*}{ Indicator } & \multicolumn{3}{|c|}{ Administrators } & \multicolumn{3}{|c|}{ Teachers } \\
\hline & Mean & SD & VI & Mean & SD & VI \\
\hline $\begin{array}{l}\text { 1. instills progress in the pupils } \\
\text { the value and importance of } \\
\text { forests or trees }\end{array}$ & 3.29 & .70548 & $\mathrm{p}$ & 3.33 & .67138 & $\mathrm{P}$ \\
\hline $\begin{array}{l}\text { 2.permits students to actively take } \\
\text { part activities such as: tree } \\
\text { planting that are in compliance to } \\
\text { policies of DENR and DepEd }\end{array}$ & 3.14 & .71521 & $\mathrm{P}$ & 3.13 & .75382 & $\mathrm{P}$ \\
\hline $\begin{array}{l}\text { 3. implants in the pupils the } \\
\text { importance of urban greening and } \\
\text { reforestation }\end{array}$ & 3.24 & .66513 & $\mathrm{P}$ & 3.27 & .70919 & $\mathrm{P}$ \\
\hline $\begin{array}{l}\text { 4. identifies and plants trees in } \\
\text { flood prone areas, tree-less areas, } \\
\text { and areas near bodies of water }\end{array}$ & 3.08 & .88539 & $\mathrm{P}$ & 3.05 & .79644 & $\mathrm{P}$ \\
\hline $\begin{array}{l}\text { 5. provides a nursery for trees that } \\
\text { are considered as endangered } \\
\text { species inside the school, such as } \\
\text { narra, molave, kamagong, etc. }\end{array}$ & 2.94 & .98165 & $\mathrm{P}$ & 2.95 & .84490 & $\mathrm{P}$ \\
\hline $\begin{array}{l}\text { 6. researches and acts accordingly } \\
\text { with the approval from DENR in } \\
\text { designating the right areas for tree } \\
\text { planting } \\
\text { conducts action researches }\end{array}$ & 2.52 & 1.02952 & $\mathrm{P}$ & 2.73 & .92478 & $\mathrm{P}$ \\
\hline $\begin{array}{l}\text { 7. participates with the local } \\
\text { government, school officials, } \\
\text { DepEd, and DENR to show } \\
\text { support in urban greening }\end{array}$ & 2.68 & .91273 & $\mathrm{P}$ & 2.86 & .80038 & $\mathrm{P}$ \\
\hline $\begin{array}{l}\text { 8. joins with the local } \\
\text { government, DENR, and DepEd } \\
\text { in reforestation activities }\end{array}$ & 2.71 & .97432 & $\mathrm{P}$ & 2.86 & .84861 & $\mathrm{P}$ \\
\hline Composite Mean & 2.95 & .69942 & $\mathrm{P}$ & 3.02 & .65992 & $\mathrm{P}$ \\
\hline
\end{tabular}

On the level of sustainable development practices, as assessed by the grouped respondents in terms of energy conservation, with a composite mean of 3.21 and SD of .55502 for administrators and 3.21 composite mean and SD .52595 for teachers, both groups have practiced energy conservation in sustaining development among their school. 
Teachers' integration of environmental awareness and sustainable development practices in elementary schools

Table 12

Sustainable development practices as assessed by the grouped respondents in terms of energy conservation

\begin{tabular}{|c|c|c|c|c|c|c|}
\hline \multirow{2}{*}{ Indicator } & \multicolumn{3}{|c|}{ Administrators } & \multicolumn{3}{|c|}{ Teachers } \\
\hline & Mean & SD & VI & Mean & SD & VI \\
\hline $\begin{array}{l}\text { 1. guarantees that energy is } \\
\text { preserved by turning off } \\
\text { equipment, lights, appliances, etc } \\
\text { at night or unused times }\end{array}$ & 3.57 & .61472 & HP & 3.53 & .60366 & HP \\
\hline $\begin{array}{l}\text { 2.promotes monitoring of pupils } \\
\text { in energy saving and usage and } \\
\text { contributes energy-saving } \\
\text { activities }\end{array}$ & 3.48 & .69229 & $\mathrm{P}$ & 3.44 & .61006 & $\mathrm{P}$ \\
\hline $\begin{array}{l}\text { 3. promotes energy conservation } \\
\text { in respective homes }\end{array}$ & 3.59 & .52777 & HP & 3.50 & .57529 & HP \\
\hline $\begin{array}{l}\text { 4.establishes rules, guidelines, } \\
\text { and standards on energy usage } \\
\text { around the school }\end{array}$ & 3.37 & .62994 & $\mathrm{P}$ & 3.42 & .61728 & $\mathrm{P}$ \\
\hline $\begin{array}{l}\text { 5. encourages pupils to start } \\
\text { campaigns within the community } \\
\text { regarding conservation of energy }\end{array}$ & 3.24 & .71198 & $\mathrm{P}$ & 3.10 & .75139 & $\mathrm{P}$ \\
\hline $\begin{array}{l}\text { 6. appoints a group to help } \\
\text { monitor energy usage in school } \\
\text { like a pupil energy group or a } \\
\text { pupil energy commission }\end{array}$ & 3.02 & .87052 & $\mathrm{P}$ & 3.03 & .78261 & $\mathrm{P}$ \\
\hline $\begin{array}{l}\text { 7.invites key speakers to give } \\
\text { detailed seminars, lectures, etc, } \\
\text { regarding on how to conserve } \\
\text { energy }\end{array}$ & 2.75 & 1.04678 & $\mathrm{P}$ & 2.88 & .89590 & $\mathrm{P}$ \\
\hline $\begin{array}{l}\text { 8.develops and studies other } \\
\text { possible energy sources such as } \\
\text { solar panels }\end{array}$ & 2.65 & 1.04971 & $\mathrm{P}$ & 2.84 & .93008 & $\mathrm{P}$ \\
\hline Composite Mean & 3.21 & .55502 & $P$ & 3.21 & .52595 & $\mathrm{P}$ \\
\hline
\end{tabular}

Data on the substantial difference comparing the calculations of the two sets of respondents on the degree of integration of environmental awareness shows that waste management has a mean of 3.30 and SD of .44418 for the head teacher and 3.28 mean and SD of .45647 for the teacher. With a difference of .28 in the mean, the group has a $0.1196 \mathrm{t}$ - value and a $.45328 \mathrm{p}$-value. This means that the administrators have extensively integrated waste management practices among students. On pollution, administrators have 3.38 mean and SD of .55454 while teachers have 3.32 mean and .45216 of SD. With T- the value of 0.53326 and p-value of .300358 , data shows that administrators have most likely integrated pollution than teachers. Forest conservation administrators have a mean of 3.24 and SD of .44929, and teachers have 3.21 mean and .53326 SD. With this, they attain $0.53326 \mathrm{t}$ value and .300358 p-value. Which infers that administrators integrated forest conservation often than teachers? Lastly, on climate change, heads have a 3.18 mean and SD of .48808 . Close to that, teachers have a 3.17 mean and SD of .52470. A t- the value of 0.02915 and p-value of .488578 has been gauge. It implies that administrators and teachers both integrate climate change.

Table 13

Difference between the evaluation of the two groups regarding extent of integration of environmental awareness

\begin{tabular}{|c|c|c|c|c|c|}
\hline \multirow{3}{*}{$\begin{array}{c}\text { Waste } \\
\text { Management }\end{array}$} & & Mean & SD & t-value & p-value \\
\hline & Administrators & 3.30 & .44418 & \multirow{2}{*}{0.1196} & \multirow[b]{2}{*}{.45328} \\
\hline & Teachers & 3.28 & .45647 & & \\
\hline \multirow{3}{*}{ Pollution } & & Mean & SD & t-value & p-value \\
\hline & Administrators & 3.38 & .44929 & \multirow{2}{*}{0.78777} & \multirow{2}{*}{.221984} \\
\hline & Teachers & 3.32 & .45216 & & \\
\hline \multirow{3}{*}{ Forest Conservation } & & Mean & SD & t-value & $\mathrm{p}$-value \\
\hline & Administrators & 3.24 & .55454 & \multirow{2}{*}{0.53326} & \multirow{2}{*}{.300358} \\
\hline & Teachers & 3.21 & .53326 & & \\
\hline \multirow{3}{*}{$\begin{array}{l}\text { Climate } \\
\text { Change }\end{array}$} & & Mean & SD & t-value & p-value \\
\hline & Administrators & 3.18 & .48808 & \multirow{2}{*}{0.02915} & \multirow{2}{*}{.488578} \\
\hline & Teachers & 3.17 & .52470 & & \\
\hline
\end{tabular}

Data on the substantial difference comparing the calculations of the two sets of respondents on the degree of 
Nasol, R. J.

sustainable development practices presents that proper waste disposal administrators have 3.30 mean and .49106 SD. In contrast, teachers have 3.23 mean and .51414 SD. They have t- the value of 0.48219 and a p-value of .31856. The data suggests that administrators have an increased level of sustainable development practices than teachers when it comes to proper waste disposal. On the other hand, recycling has a mean of 3.34 and SD of .49555 for the head teacher and 3.33 mean and SD of 51546 for the teacher. With this, the group has a .009968 $\mathrm{t}$ - value and a $.461005 \mathrm{p}$-value. This means that administrators and teachers have almost the same degree of sustainable development practices in recycling. Composting, on the other hand, administrators have 2.95 mean and SD of .73185 while teachers have 3.09 mean and .65838 SD. With a t- value of -1.21297 and a p-value of .122606, data shows that teachers have improved the level of sustainable development practices in composting the opposite of the administrators. However, both administrators and teachers have a mean of 3.21 and SD of .69942, and teachers have 3.02 mean and .65992 SD. With this, they attain a $-057837 \mathrm{t}$ - value and a .286102 p-value. This infers that teachers have a greater degree of sustainable development actions in planting trees than administrators. Lastly, on climate change, heads have 3.18 mean and SD of .55502 and .52595 , respectively. At the value of -0.05332 and p-value of .479115 has been gauge. This implies that both administrators and teachers are almost on the same level of sustainable development practices regarding climate change.

\section{Table 14}

Difference between the assessments of the two groups regarding level of maintainable practices in development

\begin{tabular}{|c|c|c|c|c|c|}
\hline \multirow{3}{*}{ Proper Waste Disposal } & & Mean & SD & t-value & p-value \\
\hline & Administrators & 3.30 & .49106 & \multirow{2}{*}{0.48219} & \multirow{2}{*}{.31856} \\
\hline & Teachers & 3.23 & .51414 & & \\
\hline \multirow{3}{*}{ Recycling } & \multirow{4}{*}{$\begin{array}{c}\text { Administrators } \\
\text { Teachers }\end{array}$} & Mean & SD & t-value & p-value \\
\hline & & 3.34 & .49555 & \multirow{2}{*}{.009968} & \multirow{2}{*}{.461005} \\
\hline & & 3.33 & .51546 & & \\
\hline \multirow{4}{*}{ Composting } & & Mean & $\mathrm{SD}$ & t-value & $\mathrm{p}$-value \\
\hline & Administrators & 2.95 & .73185 & \multirow{2}{*}{-1.21297} & \multirow{2}{*}{.122606} \\
\hline & Teachers & 3.09 & .65838 & & \\
\hline & & Mean & $\mathrm{SD}$ & t-value & p-value \\
\hline \multirow{2}{*}{ Tree Planting } & Administrators & 2.95 & .69942 & \multirow{2}{*}{-057837} & \multirow{2}{*}{.286102} \\
\hline & Teachers & 3.02 & .65992 & & \\
\hline \multirow{3}{*}{$\begin{array}{c}\text { Energy } \\
\text { Conservation }\end{array}$} & & Mean & SD & t-value & p-value \\
\hline & Administrators & 3.21 & .55502 & \multirow{2}{*}{-0.05332} & \multirow{2}{*}{.479115} \\
\hline & Teachers & 3.21 & .52595 & & \\
\hline
\end{tabular}

Data in regards to the important relationship between the extent of the teachers of integration of environmental mindfulness and level of sustainable development practices illustrates the computed $x^{2} x^{2}$ value of Recycling $\left(x^{2} x^{2}=5.895, \mathrm{df}=8\right.$, Sig. $\left.=.016\right)$ leads to rejecting the null hypothesis which means that recycling has a significant relationship on teachers' extent of integration of environmental awareness and level of sustainable development practices. However, waste Management $\left(x^{2} x^{2}=1.425, \mathrm{df}=8\right.$, Sig. $\left.=.234\right)$, pollution

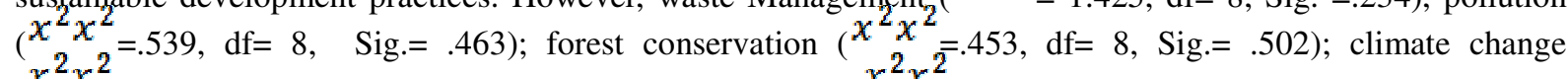
$\left(x^{2} x^{2}=.029, \mathrm{df}=8\right.$, Sig.= .865), proper waste disposal $\left(x^{2} x^{2}=.010,{ }_{2} \mathrm{df}=8\right.$, Sig.= .920); lesson Planning $\left(x^{2} x^{2}=.210, \mathrm{df}=8\right.$, Sig.= .272); instructional materials/resources $\left(x^{2} X^{2}=1.153, \mathrm{df}=8\right.$, Sig. $\left.=284\right)$; and assessment tools and evaluation $\left(x^{2} X^{2}=.420, \mathrm{df}=8\right.$, Sig.=517) lead to accept the hypothesis. This means that these factors have no significant relationship with the teachers' extent of integration of environmental mindfulness and level of sustainable development practices. 
Teachers' integration of environmental awareness and sustainable development practices in elementary schools

\section{Table 15}

Substantial connection between the extent of awareness of integration of teachers

\begin{tabular}{|c|c|c|c|c|c|}
\hline Source of Variation & $x^{2}$ Value & $\mathrm{df}$ & Sig. & Decision & Remarks \\
\hline Waste Management & 1.425 & 8 & .234 & Accept & NS \\
\hline Pollution & .539 & 8 & .463 & Accept & NS \\
\hline Forest Conservation & .453 & 8 & .502 & Accept & NS \\
\hline Climate change & .029 & 8 & .865 & Accept & NS \\
\hline Proper Waste Disposal & .010 & 8 & .920 & Accept & NS \\
\hline Lesson Planning & .210 & 8 & .272 & Accept & NS \\
\hline Instructional Materials/Resources & 1.153 & 8 & .284 & Accept & NS \\
\hline Recycling & 5.895 & 8 & .016 & Reject & S \\
\hline Assessment Tools and Evaluation & .420 & 8 & .517 & Accept & NS \\
\hline
\end{tabular}

\section{Conclusions}

Most of the respondents are rank and file teachers since only some are administrators. As with gender, this research is dominated by females and whose age ranges from late and young adulthood. This means that both groups (administrators and teachers) are mature enough to know about environmental awareness and sustainable development. There is a moderate extent of integration on environmental awareness as assessed in terms of managing waste, conserving forests, pollution, and climate change which means that both administrators and teachers should update environmental concepts to examine and contextualize environmental issues better and provide sufficient learning outcomes. This means that the school should maximize the opportunity to sustain and improve the cooperation of local and national agencies to utilize more efficient and unified information on environmental education.

On the sustainable development practices classified as proper disposal of waste, composting, recycling, planting of trees, and conservation of energy, it has been seen that administrators and teachers both have been practicing activities promoting environmental awareness and sustainable development. Awareness is the key to making an effort to protect the surroundings. Ensuring that the requests of the upcoming generations are justified by the resources of the planet, administrators and teachers must step up in teaching and practicing sustainable development in school. There is a significant difference between the assessment in terms of the extent of awareness in environment integration and sustainability practices. Administrators and teachers must work hand in hand in delivering education for sustainability. Students can see the importance of the studies done in the classrooms to raise awareness regarding the environment. Students also become engaged in the issues of the real world and develop skills to be critical thinkers and future promoters. No significant relationship has been found between the teachers' extent of integration of awareness in the environment and the level of practice of sustainable development. Proposed Action Plan may be prepared to enhance Environmental awareness and Sustainable development in Selected Elementary school in the District of Taytay.

\section{References}

Baring, R. del Castillo, F., \& Guanzon, M. (2020). Climate change and service learning in light of "Laudato Si": Reviewing educators' perceptions. The International Journal of Climate Change: Impacts and Responses, 12(1), 1-12. https://doi.org/10.18848/1835-7156/CGP/v12i01/1-12

Department of Education. (2003). DO 72, s. 2003: Establishment of the Youth for Environment in Schools (YES) Organization.

Department of Education. (2011). DO 52, s. 2011: Strengthening Environmental Education in Public and Private 
Nasol, R. J.

Schools.

Labog, R. A. (2018). Teachers' integration of environmental awareness and sustainable development practices mindoro state college of agriculture and technology Calapan City. Asia Pacific Journal of Multidisciplinary Research.

Mwendwa, B. (2015). Learning for sustainable development: Integrating environmental education in the curriculum of ordinary secondary schools in Tanzania. Sustainable Ecosystem and Biodiversity Management.

Ravago, M., Roumasset, J., \& Balisacan, A. (2009). Economic policy for sustainable development vs. greedy growth and in the pursuit of sustainable development. Southeast Asian Studies, 9, 1-43.

Sachs, J. D. (2012). From millennium development goals to sustainable development goals. The Lancet, 379(9832), 2206-2211. https://doi.org/10.1016/S0140-6736(12)60685-0 